\title{
ANALISIS EFEKTIVITAS DAN KONTRIBUSI PENERIMAAN PAJAK REKLAME TERHADAP PENDAPATAN ASLI DAERAH KABUPATEN PEKALONGAN
}

\author{
Rizka Ariyanti ${ }^{1}$, Singgih Setiawan $^{2}$, Nur Cahyati ${ }^{3}$ \\ ${ }^{1,2,3)}$ Politeknik Pusmanu
}

\begin{abstract}
The purpose of this study was to determine the effectiveness and contribution of advertisement tax revenue to local revenue in Pekalongan Regency in 2014-2018. This study uses secondary data obtained from the Regional Financial Management Agency of Pekalongan Regency. The research method used is descriptive method and data collection techniques. Observations were made using observation, interview, documentation and literature study techniques. The method in this study uses qualitative and descriptive research types.

The results of this study indicate that the effectiveness of advertisement tax revenue during the period 2014 - 2018 has a ratio of more than $100 \%$ so it can be said to be very effective. The contribution of advertisement tax to Pekalongan Regency's Regional Revenue (PAD) during the period 2014 - 2018 with the contribution ratio is still below $10 \%$ so it is said to be very less.
\end{abstract}

Keywords : Effectiveness, Contribution, Original Regional Revenue

Correspondence to : rizkaariyanti81@gmail.com

\section{PENDAHULUAN}

Negara Indonesia merupakan negara yang menganut sistem otonomi daerah dalam menjalankan pemerintahannya. Otonomi daerah sendiri merupakan salah satu wujud reformasi terhadap penyelenggaraan pemerintahan daerah provinsi/kabupaten/kota demi mengantisipasi berbagai tuntutan perubahan ketatanegaraan baik secara sosial maupun politik yang berasal dari dalam negeri maupun luar negeri.

Otonomi daerah menuntut masingmasing daerah untuk mempersiapkan sumber daya manusia yang baik, sumber keuangan yang cukup serta sarana dan prasarana yang memadai dalam pelaksanaannya. Faktor keuangan merupakan aspek utama yang dititikberatkan dalam pelaksanaan otonomi daerah, karena pada hakikatnya otonomi daerah menuntut usaha pemerintah daerah untuk secara mandiri membiayai pengeluaran-pengeluarannya sehubungan dengan program-program yang dilaksanakan oleh pemerintah suatu daerah. Sebab itu, pemerintah daerah wajib aktif menggali potensi pembiayaan, baik melalui intensifikasi yaitu dengan pemanfaatan secara optimal sumber pendapatan daerah.

PAD adalah pendapatan daerah yang murni yang bersumber dari tempat sendiri dan perlu untuk terus ditingkatkan penerimaannya, hal ini untuk membantu 
menyokong sebagian biaya yang diperlukan dalam penyelenggaraan pemerintahan dan kegiatan pembangunan yang semakin meningkat dari masa ke masa.

Dalam rangka optimalisasi pendapatan daerah, Pemerintah Kabupaten Pekalongan memberlakukan beragam jenis pajak daerah, yang tentunya pemberlakuannya juga disesuaikan dengan peraturan-peraturan perundang-undangan lebih tinggi yang berlaku di Indonesia. DPRD sebagai lembaga tinggi legislatif daerah yang merupakan mitra pemerintah daerah, juga ikut berperan serta dalam rangka penetapan target masingmasing komponen penerimaan pajak daerah dan retribusi daerah Kabupaten Pekalongan di setiap awal tahun anggaran. Dalam menentukan target penerimaan pajak daerah, aparatur pemerintah juga selalu memperhatikan aspek yang penting yang secara teknis berpengaruh pada penerimaan keuangan daerah pada umumnya yaitu situasi dan kondisi perekonomian serta suasana politik daerah. Penerimaan pajak daerah Kabupaten Pekalongan diperoleh dari berbagai jenis pajak, seperti pajak bumi dan bangunan, pajak hiburan, pajak parkir, pajak bea hak atas tanah dan bangunan, pajak air bawah tanah dan air permukaan, pajak reklame, pajak restoran, pajak penerangan jalan dan lain-lain.

Permasalahan yang dihadapi BPKD Kabupaten Pekalongan pada sektor pajak reklame ini adalah kurangnya kesadaran dan peran serta masyarakat dalam meningkatkan pajak reklame ini, disebabkan wajib pajak banyak yang tidak memperpanjang masa pajak reklame. Salah satu contohnya adalah adanya reklame yang tanpa ijin pemasangan dari pemerintah kota ataupun reklame yang perijinannya sudah mati, selain itu juga banyaknya reklame yang illegal dan tidak tertata dengan rapi sehingga dapat merusak pemandangan, hal-hal tersebut yang dapat mengurangi penerimaan pajak reklame.
Alfan
A. Lamia

(2015:790)

mendefinisikan pajak daerah adalah iuran wajib yang dilakukan oleh daerah kepada orang pribadi atau badan tanpa imbalan langsung yang seimbang, yang dapat dipaksakan berdasarkan peraturan perundang-undang yang berlaku, yang digunakan untuk membiayai penyelenggaraan pemerintahan daerah dan pembangunan daerah.

Cindy Y. Wenur (2018:475), pajak daerah terdiri dari pajak provinsi dan pajak kabupaten/kota yang dikumpulkan oleh pemerintah daerah dan dipakai untuk membiayai pengeluaran daerah.

Cindy Y. Wenur (2018:475) mengemukakan bahwa Pendapatan Asli Daerah (PAD) merupakan pendapatan yang diperoleh pemerintah daerah atas pelaksanaan kegiatan pemerintahan dan pelayanan kepada masyarakat, serta pemanfaatan sumber daya yang dimiliki oleh pemerintah daerah.

Markus Stenny Sarunda yang (2018:274) Pendapatan Asli Daerah (PAD) yaitu penerimaan yang diperoleh daerah dari sumber-sumber dalam wilayahnya sendiri yang dipungut berdasarkan peraturan daerah seseuai dengan peraturan perundang-undang yang berlaku.

Pengertian Pendapatan Asli Daerah menurut Undang-Undang Nomor 28 Tahun 2009 yaitu sumber keuangan daerah yang digali dari wilayah daerah yang bersangkutan yang terdiri dari hasil pajak daerah, hasil retribusi daerah, hasil pengelolaan kekayaan daerah yang dipisahkan dan lain-lain pendapatan asli daerah yang sah.

Menurut Mahmudi (2010:24) "pajak yang cukup potensial dan memiliki keunggulan antara lain lokasi objek pajak 
yang jelas dan mudah diidentifikasi, cukup mengambang (bouyant), relatif mudah untuk diimplementasikan, dan pertumbuhannya relatif stabil".

Menurut Markus Stenny Sarundayang (2018:275) reklame merupakan suatu benda, alat, perbuatan, atau media yang bentuk dan corak ragamnya dirancang untuk tujuan komersial memperkenalkan, menganjurkan, mempromosikan, atau untuk menarik perhatian umum terhadap barang, jasa,orang, atau badan, yang dapat dilihat, dibaca didengar, dirasakan, dan atau dinikmati oleh umum.

Menurut Alfan A. Lamia(2015:793) "Efektivitas adalah relasi suatu output terhadap pencapaian suatu sasaran atau tujuan. Dikatakan efektif bila prosedur kegiatan tersebut memperoleh sasaran atau tujuan akhir kebijakan (spending whisely) Semakin efektif proses kerja suatu unit organisasi, berarti capaian sasaran/tujuan yang dituju atas output yang dihasilkan semakin besar.

TABEL 1. Interpretasi Nilai Efektivitas

\begin{tabular}{ll}
\hline Persentase & Kriteria \\
\hline$>100 \%$ & Sangat efektif \\
$90-100 \%$ & Efektif \\
$80-90 \%$ & Cukup Efektif \\
$60-80 \%$ & Kurang Efektif \\
$<60 \%$ & Tidak Efekti
\end{tabular}

Sumber: Depdagri, Kepmendagri No. 47 Tahun 1999

Efektivitas pajak daerah

$$
\begin{aligned}
& =\frac{\text { realisasi penerimaan pajak daerah }}{\text { target penerimaan pajak daerah }} \\
& \times 100 \%
\end{aligned}
$$

Menurut Reka Wijayanti(2018:20), Analisis kontribusi yaitu untuk mengetahui seberapa besar kontribusi dari pajak reklame terhadap PAD. Semakin besar nilai kontribusi yang diberikan maka akan semakin baik kontribusi yang diberikan terhadap PAD Kota malang. Dan sebaliknya, semakin rendah nilai yang diberikan maka kontribusi yang diberikan kurang baik.

TABEL 2. Interprestasi criteria kontribusi pajak Rekalme

\begin{tabular}{ll}
\hline \multicolumn{1}{c}{ Presentasi (\%) } & \multicolumn{1}{c}{ Kriteria } \\
\hline $0.00 \%-10 \%$ & Sangat Kurang \\
\hline $10,10 \%-20 \%$ & Kurang \\
\hline $20,10 \%-30 \%$ & Sedang \\
\hline $30,10 \%-40 \%$ & Cukup Baik \\
\hline $40,10 \%-50 \%$ & Baik \\
\hline$>50 \%$ & Sangat baik \\
\hline
\end{tabular}

Sumber: Tim Litbang Depdagri-Fisipol UGM

Kontribusi pajak daerah

$$
=\frac{\text { jumlah realisasi pajak daerah }}{\text { jumlah realisasi PAD }} \times 100 \%
$$

Berdasarkan kajian teori yang sudah dikemukakan diatas, maka kerangka pemikiran dalam penelitian ini adalah sebagai berikut:

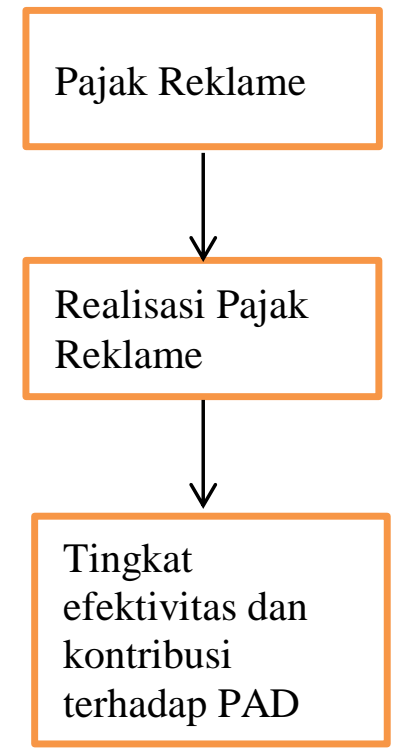

Gambar 1. Kerangka Berpikir Sumber : berbagai jurnal diolah 
Keterangan

1. Pajak reklame adalah biaya yang harus di bayar agar mendapatkan izin penyelenggaraan reklame.

2. Realisasi pajak reklame, Data yang diperolehan dari penerimaan pajak reklame selama periode satu tahun.

3. Efektivitas dan kontribusi terhadap PAD Efektivitas sendiri adalah pencapaian suatu target dan kontribusi terhadap Pendapatan Asli Daerah adan suatu sumbangan dari pajak reklame untuk Pendapatan Asli Daerah

\section{METODE PENELITIAN}

Untuk memperoleh data yang berhubungan dengan penelitian maka metode pengambilan data dilakukan dengan cara mengambil langsung data ditempat penelitian dengan cara:

1. Wawancara

Wawacara menurut Ningrum (2015:39), digunakan sebagai teknik pengumpulan data apabila penelitian akan melaksanakan studi pendahuluan untuk menemukan permasalahan yang harus diteliti, dan juga peneliti ingim mengetahui hal-hal dari responden yang lebih mendalam dan jumlah respondennya sedikit atau kecil. Wawancara yang dilakukan oleh peneliti dilakukan secara semi terstruktur artinya kalimat dan urutan yang diajukan peneliti tidak harus mengikuti ketentuan secara ketat.

\section{Studi Pustaka}

Studi pustaka dilakukan dengan mempelajari dan membaca berbagai peraturan perundangan serta bahan-bahan pustaka yang berkaitan dengan kajian penerimaan pajak reklame.Selain berupa peraturan dan buku, sumber data juga diambil dari internet.
Analisis data kualitatif yaitu menguraikan serta menginterpretasikan data yang diperoleh di lapangan dari para informan. Dalam penelitian ini, penulis menganalisis secara langsung data-data yang peneliti peroleh ketika melakukan observasi dan wawancara. Data-data yang diperoleh akan diolah dan disajikan dalam bentuk deskriptif yang bertujuan untuk mengemukakan permasalahan dan menemukan solusi dengan disertai dengan teori-teori yang mendukung yaitu:

a. Pengumpulan Data

Pengumpulan data yaitu mengumpulkan data yang ada di lokasi penelitian dengan melakukan observasi, wawancara, dokumentasi dan studi pustaka dengan menentuka strategi pengumpulan data yang tepat dan menentukan fokus serta pendalaman data pada proses pengumpulan data berikutnya.

b. Reduksi Data

Data yang diperoleh dari observasi, wawancara dan dokumentasi dicatat dengan rinci dengan memfokuskan dan memilih halhal yang penting, sehingga data yang diperoleh dapat memberikan gambaran yang jelas mengenai topik yang sedang diteliti.

c. Penyajian Data

Setelah melakukan reduksi data, penulis menyajikan data dalambentuk teks yang bersifat deskriptif.

d. Penarikan Kesimpulan

Setelah data-data terangkum dan dijabarkan, penulis akan membuat kesimpulan yang nantinya dapat digunakan untuk menjawab rumusan masalah 
HASIL PENELITIAN

\section{Perhitungan Efektivitas Penerimaan Pajak} Reklame

Tingkat efektivitas penerimaan pajak reklame dapat dihitung dengan membandingkan antara realisasi penerimaan pajak reklame dengan anggaran pajak reklame yang telah ditetapkan. Efektivitas penerimaan pajak reklame berpotensi efektif apabila mencapai minimal satu sampai dengan $100 \%$. Apabila hasil perhitungan menunjukkan $<60 \%$ maka berpotensi tidak efektif. Dan apabila hasil perhitungann $>100 \%$ maka menunjukkan sangat efektif.

Untuk mengetahui besarnya efektivitasnya anggaran dan realisasi penerimaan pajak reklame di BPKD Kabupaten Pekalongandapat dihitung dengan menggunakan rumus:

Efektivitas pajak reklame

$=\frac{\text { Realisasi penerimaan pajak reklame }}{\text { Target penerimaan pajak reklame }} \times 100 \%$

Sumber: Kepmendagri No.690.900.327 Tahun 1996 (Firdausy, 2017:91)

TABEL 3. Perhitungan Efektifitas Penerimaan Pajak Reklame

(ribuan)

\begin{tabular}{|c|c|c|c|}
\hline Tahun & $\begin{array}{c}\text { Target } \\
\text { penerimaan } \\
\text { pajak } \\
\text { reklame }\end{array}$ & $\begin{array}{c}\text { Realisasi } \\
\text { penerimaan } \\
\text { pajak } \\
\text { reklame }\end{array}$ & $\begin{array}{l}\text { Efektivit } \\
\text { as } \\
(\%)\end{array}$ \\
\hline 2014 & $\mathrm{Rp} 297.928$ & $\operatorname{Rp} 406.136$ & $136,32 \%$ \\
\hline 2015 & $\mathrm{Rp} 434.835$ & Rp 552.370 & $127,03 \%$ \\
\hline 2016 & Rp 516.960 & Rp 691.317 & $133,73 \%$ \\
\hline 2017 & Rp 692.135 & Rp 719.614 & $103,97 \%$ \\
\hline 2018 & Rp 1.040.760 & Rp 1.071.415 & $102,95 \%$ \\
\hline
\end{tabular}

Sumber: BPKD Kabupaten Pekalongan

Pada tahun 2014 BPKD menargetkan pajak reklame sebesar Rp 297.928.000 dengan realisasi yang di dapatkan oleh
BPKD yaitu sebesar Rp 406.135.682 dengan presentase $136,32 \%$ menunjukkan sangat efektif. Selanjutnya di tahun 2015 BPKD menaikkan anggarannya sebesar $\mathrm{Rp}$ 434.835.000 dengan realisasi yang di peroleh sebesar Rp 552.370.303 dengan presentase $127,03 \%$ tetapi mengalami penurunan dari tahun sebelumnya. Pada tahun 2016 mengalami kenaikan lagi dengan anggaran Rp 516.959.755 dengan realisasi yang di peroleh Rp 691.316.978 presentase 133,73\%. Di tahun 2017 mengalami penurunn drastis dengan anggaran $\mathrm{Rp}$ 692.135.000 dengan mendapatkn realisasi sebesar $\mathrm{Rp}$ 719.613.716 dengan presentase $103,97 \%$. Dan pada tahun 2018 mengalami penurunan lagi dengan anggaran $\mathrm{Rp}$ 1.040.760.000 mendapatkan realisasi sebesar $\mathrm{Rp}$ 1.071.414.845 dengan prsentase $102,95 \%$ dengan kriteria sangat efektif.

\section{Perhitungan Penerimaan Pajak Reklame Terhadap PAD}

Analisis yang digunakan untuk mengetahui berapa besar penerimaan pajak reklame terhadap Pendapatan Asli Daerah (PAD) di Kabupaten Pekalongan yaitu dengan menggunakan perbandingan realisasi pajak reklame dengan realisasi PAD. Dari hasil tersebut dapat diketahui apakah pajak reklame sangat berkontribusi atau tidaknya dalam menyumbangakan Pendapatan Asli Daerah di Kabupaten Pekalongan.

Berikut ini tabel interprestasi kriteria kontribusi pajak reklame terhadap PAD Kabupaten Pekalongan. 


\begin{tabular}{cc}
\hline \multicolumn{2}{c}{ TABEL 4. Intresprestasi Kriteria } \\
KontribusiPajak ReklameTerhadap PAD \\
Kabupaten Pekalongan \\
\begin{tabular}{cc} 
Presentasi (\%) & Kriteria \\
\hline $0.00 \%-10 \%$ & Sangat Kurang \\
\hline $10,10 \%-20 \%$ & Kurang \\
\hline $20,10 \%-30 \%$ & Sedang \\
\hline $30,10 \%-40 \%$ & Cukup Baik \\
\hline $40,10 \%-50 \%$ & Baik \\
\hline$>50 \%$ & Sangat Baik \\
\hline
\end{tabular}
\end{tabular}

Untuk mengetahui besarnya pengaruh pajak reklame terhadap Pendapatan Asli Daerah (PAD) di Kabupaten Pekalongan dapat dihitung dengan menggunakan rumus sebagai berikut:

$$
\begin{aligned}
& \text { Kontribusi } \\
& =\frac{\text { Realisasi Pajak Reklame }}{\text { Realisasi PAD }} \times 100 \%
\end{aligned}
$$

Sumber: Tim Litbang Depdagri-Fisipol UGM 1991 (Firdausy, 2017:92)

Berdasarkan rumus diatas maka kontrubusi pajak reklame terhadap Pendapatan Asli Daerah di BPKD Kabupaten Pekalongan tahun 2014-2018 dapat dihitung sebagai berikut:

TABEL 5. Kontribusi Pajak Reklame Terhadap PAD Kabupaten Pekalongan

Sumber: BPKD Kabupaten Pekalongan

1. Tahun 2014

$$
\frac{406.135 .682}{255.037 .017 .191,46} \times 100 \%=0,16 \%
$$

2. Tahun 2015

$$
\frac{552.370 .303}{251.558 .970 .833,84} \times 100 \%=0,22 \%
$$

3. Tahun 2016

$$
\frac{691.316 .978}{310.572 .581 .551,98} \times 100 \%=0,20 \%
$$

4. Tahun 2017

$$
\frac{719.613 .716}{305.394 .299 .060,77} \times 100 \%=0,23 \%
$$

5. Tahun 2018

$$
\frac{1.071 .414 .845}{312.161 .465 .557,83} \times 100 \%=0,34 \%
$$

Kontribusi pajak reklame terhadap PAD diatas, dapat dilihat bahwa dari tahun 2014-2018 mengalami kenaikan dan penurunan pada setiap tahunnya. Pada tahun 2014 PAD BPKD Kabupaten Pekalongan memperoleh realisasi PAD sebesar Rp 255.037.017.191,46 sedangkan realisasi pajak reklame sebesar $\mathrm{Rp}$ 406.135.682 dengan presentasi 0,16 yang berkriteria sangat kurang. Pada tahun 2015 mengalami kenaikan dengan realisasi PAD sebesar Rp 251.558.970.833,84 sedangkan realisasi pajak reklame sebesar $\mathrm{Rp} \quad 552.370 .303$ dengan presentasi $0,22 \%$ masuk kriteria sangat kurang. Tahun 2016 mengalami penurunan dengan realisasi PAD sebesar Rp 310.572.581.551,98 dengan realisasi pajak reklame sebesar $\mathrm{Rp}$ 691.316.978 dengan presentase $0,20 \%$ memperoleh kriteria sangat kurang. Pada tahun 2017 mengalami kenaikan lagi dengan realisasi PAD sebesar Rp 305.394.299.060,77 sedangkan realisasi pajak reklame sebesar $\mathrm{Rp} 719.613 .716$ dengan presentase sebesar $0,23 \%$ dengan kriteria sangat kurang. Sedangkan pada tahun 2018 mengalami kenaikan lagi dengan realisasi PAD sebesar Rp 312.161.465.557,83 dengan realisasi pajak daerah sebesar $\mathrm{Rp} \quad 1.071 .414 .845$ memperoleh presentase sebesar 0,34\% dengan kriteria sangat kurang. 


\section{PEMBAHASAN}

Efektivitas Penerimaan Pajak Reklame

Perhitungan yang diawali dari tahun 2014 yang menunjukkan presentase 136,32\% yang sudah memasuki kriteria sangat efektif. Selanjutnya pada tahun berikutnya yaitu tahun 2015 mengalami penurunan dengan presentase $127,03 \%$ yang diakibatkan banyak reklame yang di pasang sembarangan dan tidak mematuhi peraturan daerah.

Pada tahun 2016 adanya kenaikan pada realisasi penerimaan pajak reklame dan mengalami kenaikan presentase sebesar $133,73 \%$, sedangkan pada tahun 2017 dan 2018 mengalami perubahan peraturan Bupati Pekalongan Nommor 76 Tahun 2017 tentang perubahan kedua atas peraturan Bupati Pekalongan nomor 29 tahun 2011 tentang nilai sewa reklame, tetapi mengalami penurunan presentase.

Penerimaan Pajak Reklame Terhadap PAD

Dilihat dari perhitungan menggunakan rumus yang telah dibahas diatas, pada tahun 2014 pajak reklame hanya menyumbang kepada PAD sebesar 0,16\% dan masih sangat kurang untuk menyumbang PAD di Kabupaten Pekalongan yang diakibatkan karena masih minimnya sosialisasi terhadap pemasangan reklame di Kabupaten Pekalongan.

Di tahun 2015 mengalami kenaikan kontribusi pajak reklame terhadap PAD sebesar $0,22 \%$. Kenaikan tersebut diakibatkan sudah banyak masyarakat yang mengetahu tentang pentingnya pajak reklame untuk menambah nilai pada PAD.

Pada tahun 2016 realisasi pajak reklame terhadap Pendapatan Asli Daerah mengalami penurunan dengan presentase 0,20\% dikarenakan banyaknya wajib pajak yang belum memperpanjang masa berlaku reklame yang sudah habis sehingga mengakibatkan menurunnya Pendapatan Asli Daerah. Pada tahun 2017 dan 2018 mengalami kenaikan presentase sebesar $0,23 \%$ dan $0,34 \%$ dikarenakan wajib pajak sudah membayar perpanjangan pajak reklame.

Dalam penerimaan pajak reklame, banyak sekali gangguan-gangguan atau menghambat dalam pemasukan pajak terhadap Pendapatan Asli Daerah di BPKD Kabupaten Pekalongan. Seperti banyak wajib pajak yang belum mendaftarkan pajak reklame yang mengakibatkan penerimaan pajak reklame menjadi terhambat, selain itu juga banyak yang tidak memahami dasar hukum dari pajak reklame itu sendiri. Seharusnya para petugas memberikan sosialisasi terhadap dasar hukum dari pajak reklame agar wajib pajak dapat mengetahui dasar hukum yang wajib ditaati saat menggunakan pajak reklame. Banyak wajib pajak yang kurang menyadari dalam pemahaman pemajangan masa reklame yang diberikan oleh BPKD. Masih banyak pula yang melanggar perizinan reklame. Hal itu diakibatkan masih banyaknya reklame yang masa berlakunya habis tidak melakukan perizinan pemajangan kembali.

\section{SIMPULAN}

Berdasarkan hasil penelitian yang telah dilakukan mengenai analisis efektivitas dan kontribusi penerimaan pajak reklame terhadap pendapatan asli daerah di BPKD Kabupaten Pekalongan dapat ditarik simpulan bahwa:

1. Tingkat Efektivitas penerimaan pajak reklame dari tahun 2014-2018 sudah sangat efektif karena realisasi penerimaan pajak reklame sudah melebihi target penerimaan pajak reklame. 
2. Tingkat Kontribusi pajak reklame belum berkontribusi terhadap pendapatan asli daerah hal ini dikarenakan jumlah realisasi pajak reklame masih kurang di bandingkan dengan jumlah realisasi PAD. Hasil kontribusi penerimaan pajak reklame terhadap pendapatan asli daerah di Kabupaten Pekalongan masih sangat kurang untuk menyumbang pendapatan asli daerah.

Faktor-faktor yang dapat menghambat dalam penerimaan pajak reklame yaitu banyaknya wajib pajak yang belum mendaftarkan pajak reklamenya, selain itu banyaknya wajib pajak yang belum memahami dasar hukum dari pajak reklame dan masih minimnya pemahaman dalam perizinan pemajangan masa reklame.

\section{DAFTAR PUSTAKA}

Alfan A. Lamia,dkk. 2015. Analisis Efektivitas dan Kontribusi Pemungutan Pajak Restoran, Pajak Reklame, Dan Pajak Penerangan Jalan Pada Pendapatan Asli Daerah Kabupaten Minahasa Utara.Fakultas Ekonomi dan Bisnis, Universitas Sam Ratulangi,Manado

Aris Triyono. 2018. Analisis Pengaruh Kontribusi Pajak Reklame dan Pajak Hiburan Terhadap Pendapatan Asli Daerah (PAD) Pada Badan Pendapatan Daerah Kabupaten Indragiri Hulu. Sekolah Tinggi Ilmu Ekonomi Indragiri Rengat

Cindy Y. Wenur, dkk. 2018. Analisis Kontribusi DAN Efektivitas Pajak Daerah Sebagai Sumber Pendapatan Asli Daerah (PAD) Di Kota Bitung.Fakultas Ekonomi dan Bisnis, Universitas Sam Ratulangi,Manado Gunawan, Imam. 2016. Metode Penelitian
Kualitatif.Jakarta : Bumi Aksara.

Mahmudi. 2010. Manajemen Keuangan Daerah. Jakarta: Penerbit Erlangga

Markus Stenny Sarundayang, dkk. 2018. Analisis Potensi Dan Efektivitas Penerimaan Pajak Reklame Di Kota Manado.Fakultas Ekonomi dan Bisnis, Universitas Sam Ratulangi, Manado

Ningrum, Aminah Oktavia Cahaya. 2015. Analisis Pengamen Jalanan Di Kota Surakarta. Diakses pada tanggal 26 April 2018 dari http://eprints.ums.ac.id

Politeknik Pusmanu. 2019. Buku Panduan Praktek Kerja Lapangan dan Penulisan Tugas Akhir. Pekalongan

Reka Wijayanti, dkk. 2. Analisis Efektivitas dan Kontribusi Pajak Reklame Terhadap Pendapatan Asli Daerah (PAD) di Kota Malang.Fakultas Ekonomi, Universitas Islam Malang

Rezlyanti Kobandaha dan Heince R. N. Wokas. 2016. Analisis Efektivitas, Kontribusi Dan Potensi Pajak Reklame Dan Pajak Hotel Terhadap Pendapatan Asli Daerah Kota Kotamobagu. Fakultas Ekonomi dan Bisnis, Universits Sam Ratulangi, Manado

Subadriyah, SE., M.Si. 2017. Pajak Penghasilan. Yogyakarta: Penerbit Pustaka Pelajar

Undang-Undang No16.2009. Ketentuan Umum dan Tata CaraPerpajakan. 